\title{
Acknowledgments (and apologies)
}

We acknowledge the vision of Robert Con Davis-Undiano, Neustadt professor of English at the University of Oklahoma and editor of the literary journal World Literature Today, in developing the Ethnic Studies series for Edinburgh University Press, of which this volume is a part. Jace Weaver and Jay Stauss read an early draft of the manuscript and made many helpful comments and suggestions. Jon Velie was of special assistance in the chapter on sovereignty.

We apologize to scholars whose work we have subsumed under the rubric of Native American Studies when perhaps they think it does not belong there. The attempt to trace the intellectual underpinnings of scholarship in a new field has led us to cast a wide net. We also apologize to those who feel that their work should be included but is not mentioned in this book. The scholarship on American Indians has grown at such a phenomenal rate and is still growing even as this book goes to press - that it is impossible to mention all relevant publications.

Clara Sue Kidwell acknowledges an intellectual debt to colleagues and students in Native American Studies programs and institutions far too numerous to mention, but a few individuals deserve special thanks for thoughtful conversation and for fostering the intellectual environment out of which this book has grown. Jerome Greene, Ramon Powers, and Hoy Steele were steadfast colleagues in stressful times of change at Haskell Indian Junior College. Roger Buffalohead established the program at the University of Minnesota and gave me a chance to be part of it. Tim Dunnigan and Delores Cloud helped me understand the value of language, although I never mastered Ojibwa. Gerald Vizenor and Paula Gunn Allen 
at Berkeley challenged my thinking about literature. My faculty colleagues at the University of Oklahoma, Robert Warrior, Craig Womack, Geary Hobson, Loretta Fowler, Gus Palmer, Jr, Circe Sturm, Gary Anderson, R. Warren Metcalf, Al Hurtado, Josh Piker, Paula Conlon, Edgar Heap of Birds, and Mary Jo Watson, are doing the kind of scholarship that make Native American Studies such an exciting field. I was fortunate to be able to spend the 2003-4 academic year at the Newberry Library in Chicago, where Brian Hosmer, director of the D'Arcy McNickle Center for American Indian History, and Dan Cobb, assistant director, made me feel at home. I thank them and the Newberry staff for providing a supportive environment where I could finish work on this book. Finally, I owe special thanks to Vine Deloria, Jr, and W. Richard West, Jr. mentors in my shortlived museum career which has been such valuable experience in seeing things in new ways, as well as long-time friends. 